\title{
Enalapril for severe heart failure in infancy
}

\author{
M FRENNEAUX, R A H STEWART, C M H NEWMAN, AND K A HALLIDIE-SMITH \\ Department of Cardiology, Hammersmith Hospital and Royal Postgraduate Medical School, London
}

SUMmARY Eight infants aged between 4 days and 12 weeks with severe heart failure that was refractory to optimal conventional treatment with diuretics were treated with enalapril. The starting dose was $0.1 \mathrm{mg} / \mathrm{kg} /$ day, increasing according to response to $0.12-0.43 \mathrm{mg} / \mathrm{kg} / \mathrm{day}$. One infant with severe myocarditis did not tolerate enalapril because of hypotension and later died of intractable heart failure. Six of the remaining patients had congenital systemic to pulmonary shunts and one had a simple aortic coarctation. Two weeks after starting enalapril the clinical features of heart failure had improved in all the infants, the mean (SEM) plasma sodium concentration had increased from $129(2 \cdot 4)$ to $136(1 \cdot 1) \mathrm{mmol} / \mathrm{l}$ and plasma urea concentration had fallen from $7 \cdot 0(0 \cdot 85)$ to $2.9(0 \cdot 85) \mathrm{mmol} / \mathrm{l}$. These data suggest that enalapril is a potentially useful treatment for severe heart failure in infancy.

The standard treatment of heart failure in infancy comprises diuretics, either alone or in combination with digoxin. Digoxin has a narrow therapeutic range and its effectiveness as a postive inotropic agent (except in the short term) is in considerable doubt. ${ }^{1}$ Over the past few years the introduction of angiotensin converting enzyme inhibitors has been an important advance in the treatment of heart failure in adults but their use in children has been limited. ${ }^{2}{ }^{3}$ We report the effect of enalapril in eight infants with heart failure that was refractory to treatment with diuretics.

\section{Patients and methods}

We report our total experience with enalapril for the treatment of heart failure in infancy between January 1986 and December 1987. Infants received enalapril if they had severe heart failure despite optimal diuretic treatment and corrective surgery was either not possible or considered inappropriate. The age at which enalapril was started ranged from 4 days to 12 weeks (median 3 weeks). Individual patient characteristics are shown in the table.

A suspension of enalapril was freshly prepared before each dose by dissolving a crushed $5 \mathrm{mg}$ tablet in $5 \mathrm{ml}$ sterile water. The appropriate dose was drawn up using a calibrated $1 \mathrm{ml}$ syringe and given orally.

Treatment with diuretics was withdrawn for 24 hours before enalapril was started to ensure an adequate intravascular volume. In each case an initial dose of $0.1 \mathrm{mg} / \mathrm{kg}$ was given orally. Blood pressure was measured hourly for the first 12 hours to detect any hypotensive response to the first dose. Angiotensin $(0.1-0.3 \mathrm{mg} / \mathrm{kg} /$ minute intravenously) and intravenous fluids could be given if there was excessive hypotension after the first dose.

Diuretics were restarted about 12 hours after starting enalapril, initially at half the original dose and then adjusted according to clinical response. The dose of enalapril was gradually increased over 10-14 days to a maintenance regimen determined by clinical response but not exceeding $0.5 \mathrm{mg} / \mathrm{kg} / \mathrm{day}$. Regular clinical assessments were performed, including measurements of weight, feeding pattern, skin colour, sweatiness, respiratory rate, heart rate, liver size, and blood pressure.

Plasma urea and electrolytes were estimated 24 hours before starting enalapril, at least every 48 hours during the first week of treatment, and at least twice during the second week.

Clinical and biochemical data for the seven patients who survived at least two weeks after beginning enalapril are reported as mean (SEM).

\section{Results}

The clinical features of heart failure, drug treatment, and biochemistry 24 hours before enalapril and after two weeks treatment with enalapril are documented for each patient in the table. The time course of weight gain, increase in plasma sodium 
220 Frenneaux, Stewart, Newman, and Hallidie-Smith

Table Clinical details of each patient before and two weeks after taking enalapril

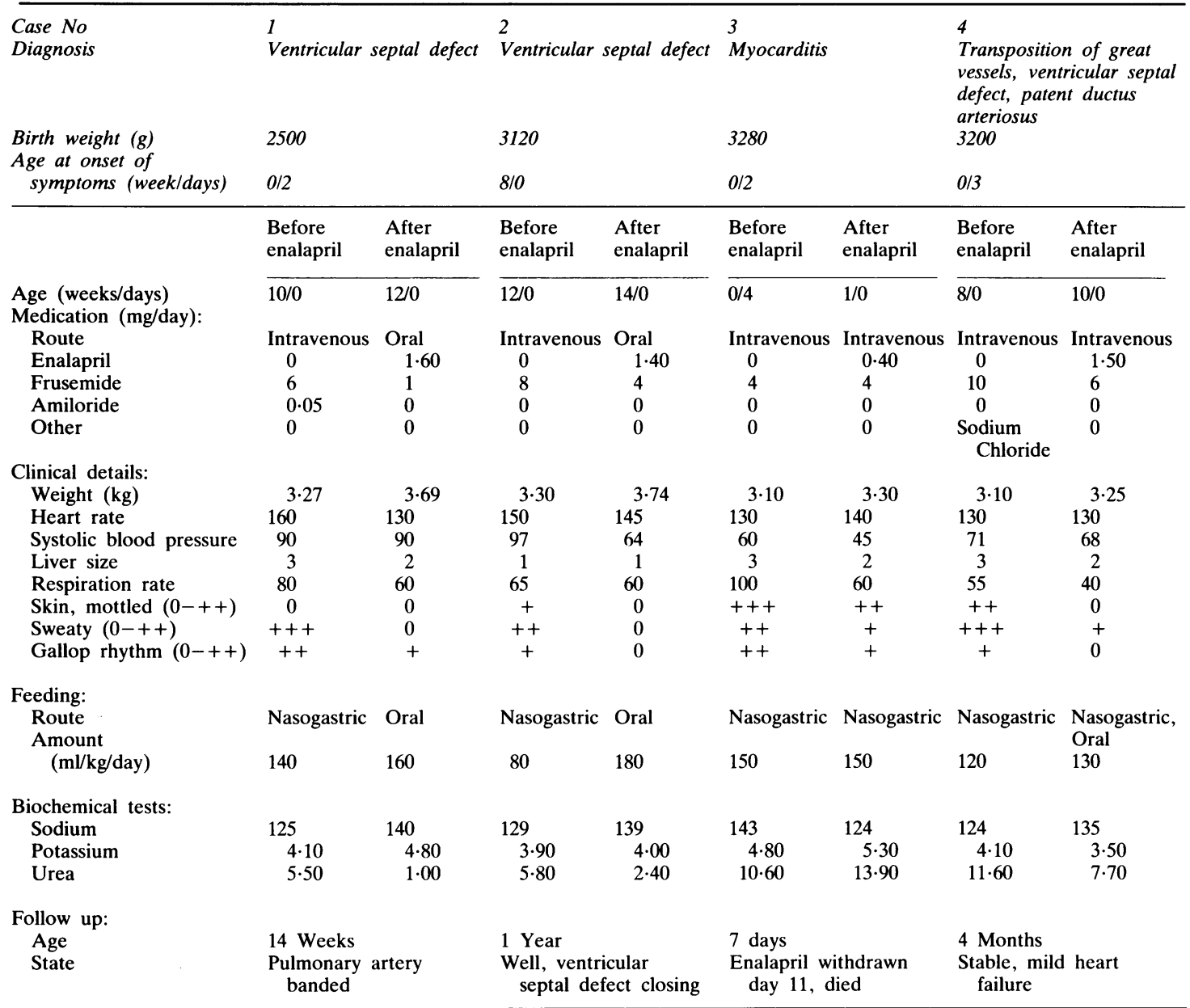

concentration, and fall in plasma urea concentration after the introduction of enalapril in a typical patient are illustrated in the figure. Systemic blood pressure fell by less than $10 \mathrm{~mm} \mathrm{Hg}$ in all cases after the first dose of enalapril.

One patient (case 3) had severe myocarditis presenting with heart failure at birth. Enalapril was started on day 4 and there was an initial improvement. On day 7, however, there was acute deterioration with a fall in systolic blood pressure from 60 to $45 \mathrm{~mm} \mathrm{Hg}$. Enalapril was discontinued. In spite of treatment with fluid replacement, intravenous angiotensin, and inotropic support the infant continued to deteriorate and died 4 days later.

Analysis of clinical and biochemical data is restricted to the seven patients who were alive two weeks after starting treatment with enalapril. There were no adverse effects in these patients. At two weeks the mean dose of enalapril was 0.26 $\mathrm{mg} / \mathrm{kg} /$ day (range $0.12-0.43 \mathrm{mg} / \mathrm{kg} /$ day). In all seven patients there was progressive improvement in skin colour, amount of sweating, and the presence or absence of a gallop rhythm during treatment. Two weeks after starting enalapril mean (SEM) liver size had decreased from $2.3(0.36) \mathrm{cm}$ to $1.2(0.24) \mathrm{cm}$ below the costal margin, and the mean respiratory rate had fallen from $63(3.2)$ to $53(2.8)$ breaths/ minute. The mean heart rate increased from 136 $(6 \cdot 4)$ to $143(4 \cdot 2)$ beats/minute and the mean systolic pressure fell from $88 \quad(4.0) \mathrm{mm} \mathrm{Hg}$ to 82 (6.5) $\mathrm{mm} \mathrm{Hg}$.

The mean dose of frusemide decreased from 1.8 


\begin{tabular}{|c|c|c|c|c|c|c|c|}
\hline \multicolumn{2}{|c|}{$\begin{array}{l}5 \\
\text { Coarctation of aorta }\end{array}$} & \multicolumn{2}{|c|}{$\begin{array}{l}6 \\
\text { Ventricular septal defect, } \\
\text { pulmonary artery stenosis }\end{array}$} & \multicolumn{2}{|c|}{$\begin{array}{l}7 \\
\text { Ventricular septal defect, } \\
\text { hypoplastic aorta and mitral } \\
\text { valve, coarctation }\end{array}$} & \multicolumn{2}{|c|}{$\begin{array}{l}8 \\
\text { Multiple ventricular septal } \\
\text { defect, pulmonary artery } \\
\text { branch stenosis }\end{array}$} \\
\hline 4530 & & 3300 & & 1940 & & 3300 & \\
\hline $2 / 6$ & & $0 / 3$ & & $0 / 1$ & & $0 / 2$ & \\
\hline $\begin{array}{l}\text { Before } \\
\text { enalapril }\end{array}$ & $\begin{array}{l}\text { After } \\
\text { enalapril }\end{array}$ & $\begin{array}{l}\text { Before } \\
\text { enalapril }\end{array}$ & $\begin{array}{l}\text { After } \\
\text { enalapril }\end{array}$ & $\begin{array}{l}\text { Before } \\
\text { enalapril }\end{array}$ & $\begin{array}{l}\text { After } \\
\text { enalapril }\end{array}$ & $\begin{array}{l}\text { Before } \\
\text { enalapril }\end{array}$ & $\begin{array}{l}\text { After } \\
\text { enalapril }\end{array}$ \\
\hline $3 / 0$ & $5 / 0$ & $2 / 6$ & $4 / 6$ & $2 / 2$ & $4 / 2$ & $2 / 5$ & $4 / 5$ \\
\hline $\begin{array}{l}\text { Intravenous } \\
0 \\
5 \\
0 \\
\text { Digoxin }\end{array}$ & $\begin{array}{l}\text { Oral } \\
\quad 0 \cdot 50 \\
0 \\
0 \\
0\end{array}$ & $\begin{array}{l}\text { Intravenous } \\
0 \\
3 \\
0 \\
0\end{array}$ & $\begin{array}{l}\text { Oral } \\
0 \cdot 60 \\
0 \\
0 \\
\text { Thiazide }\end{array}$ & $\begin{array}{c}\text { Intravenous } \\
0 \\
3 \\
0 \\
0\end{array}$ & $\begin{array}{l}\text { Intravenous } \\
0 \cdot 60 \\
3 \\
0 \\
0\end{array}$ & $\begin{array}{c}\text { Oral } \\
0 \\
3 \\
0 \\
0\end{array}$ & $\begin{array}{l}\text { Oral } \\
0 \cdot 60 \\
3 \\
0 \\
\text { Thiazide }\end{array}$ \\
\hline $\begin{array}{c}4 \cdot 24 \\
120 \\
100 \\
1 \\
60 \\
0 \\
++ \\
+\end{array}$ & $\begin{array}{c}4 \cdot 76 \\
150 \\
120 \\
1 \\
50 \\
0 \\
0 \\
0\end{array}$ & $\begin{array}{c}3 \cdot 34 \\
120 \\
80 \\
3 \\
65 \\
0 \\
0 \\
0\end{array}$ & $\begin{array}{c}3 \cdot 68 \\
160 \\
82 \\
0 \cdot 50 \\
60 \\
0 \\
0 \\
0\end{array}$ & $\begin{array}{r}2 \\
150 \\
95 \\
2 \\
60 \\
++ \\
+++ \\
++\end{array}$ & $\begin{array}{c}2 \cdot 20 \\
140 \\
80 \\
1 \\
55 \\
+ \\
+ \\
+\end{array}$ & $\begin{array}{c}3 \cdot 34 \\
120 \\
80 \\
3 \\
55 \\
0 \\
+ \\
0\end{array}$ & $\begin{array}{c}3 \cdot 68 \\
150 \\
75 \\
0 \cdot 50 \\
50 \\
0 \\
0 \\
0\end{array}$ \\
\hline Oral & Oral & Oral & Oral & Nasogastric & Nasogastric & Oral & Oral \\
\hline 160 & 160 & 150 & 160 & 150 & 150 & 150 & 160 \\
\hline $\begin{array}{l}138 \\
4 \cdot 80 \\
5\end{array}$ & $\begin{array}{r}137 \\
4 \cdot 40 \\
1.40\end{array}$ & $\begin{array}{l}125 \\
4 \cdot 70 \\
7 \cdot 50\end{array}$ & $\begin{array}{r}136 \\
5 \cdot 10 \\
3 \cdot 20\end{array}$ & $\begin{array}{r}138 \\
5 \cdot 70 \\
5 \cdot 80\end{array}$ & $\begin{array}{r}131 \\
5 \cdot 30 \\
1 \cdot 80\end{array}$ & $\begin{array}{r}125 \\
4 \cdot 70 \\
7 \cdot 50\end{array}$ & $\begin{array}{r}136 \\
5 \cdot 10 \\
3 \cdot 20\end{array}$ \\
\hline $\begin{array}{l}5 \text { Weeks } \\
\text { Coarctation } \\
\text { repaired }\end{array}$ & & $\begin{array}{l}3 \text { Months } \\
\text { Well on me } \\
\text { treatment }\end{array}$ & & $\begin{array}{l}4 \text { Weeks } \\
\text { Coarctation } \\
\text { died at } 11\end{array}$ & $\begin{array}{l}\text { cted, } \\
\text { eks }\end{array}$ & $\begin{array}{l}3 \text { Month } \\
\text { Well on } \\
\text { medica }\end{array}$ & hent \\
\hline
\end{tabular}

$\mathrm{mg} / \mathrm{kg} /$ day (range $0.9-3.2$ ) to $0.7 \mathrm{mg} / \mathrm{kg} /$ day (range $0-1 \cdot 8)$. Two patients were given chlorthiazide instead of frusemide and five patients were given oral instead of intravenous frusemide.

The mean weight increased from $3.3(0.24) \mathrm{kg}$ to $3.6(0 \cdot 29) \mathrm{kg}$ after two weeks taking enalapril. Four of the seven infants required nasogastric feeding before the introduction of enalapril, but by two weeks two of these had progressed to full bottle feeds. The mean daily feed volume increased from $135(10.5)$ to $159(5.6) \mathrm{ml} / \mathrm{kg} /$ day.

Mean plasma sodium concentration was $129(2 \cdot 4)$ $\mathrm{mmol} / \mathrm{l}$ (range 124-138) before treatment with enalapril and was abnormally low in five of the seven patients. At two weeks the plasma sodium concentration was within the normal range in all seven patients, mean $136(1 \cdot 1) \mathrm{mmol} / \mathrm{l}$ (range 135-140). The plasma potassium concentration was $4.6 \mathrm{mmol} / \mathrm{l}$ (range $3 \cdot 5-5 \cdot 3$ ) before starting enalapril and was unchanged after two weeks. No patients required potassium sparing diuretics or potassium supplements after starting enalapril. The mean plasma urea concentration was $7.0(0.85) \mathrm{mmol} / \mathrm{l}$ (range 5-11.6) before starting enalapril and fell in all seven patients to a mean of $2.9(0.85) \mathrm{mmol} / \mathrm{l}$ (range $1 \cdot 0-7 \cdot 7)$ after two weeks.

\section{Discussion}

Captopril and enalapril have gained widespread acceptance for the treatment of hypertension and heart failure in adults. There are only two reports on 


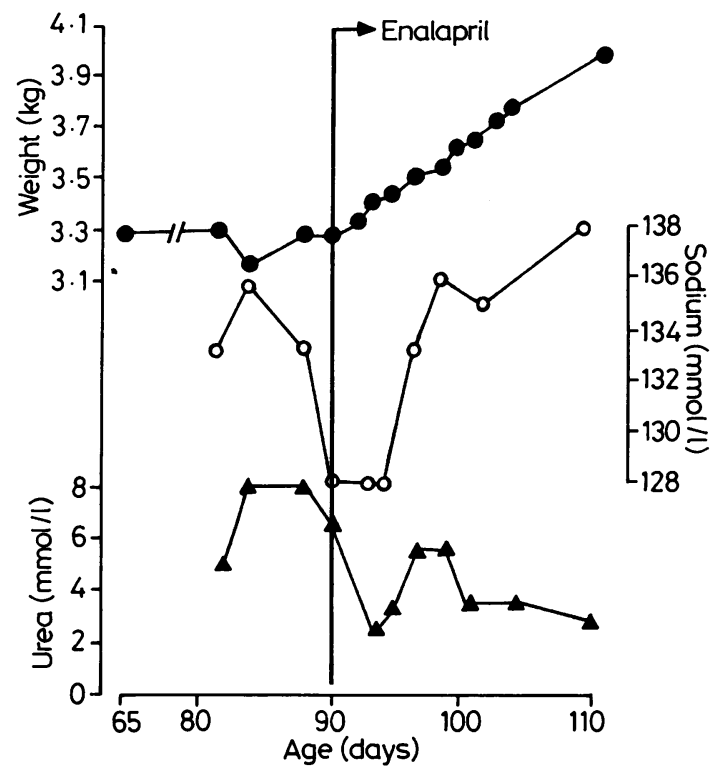

Figure Body weight, plasma sodium, and plasma urea concentrations before and after taking enalapril in an infant with a ventricular septal defect and severe heart failure (case 2).

the use of captopril for the treatment of heart failure in infants ${ }^{2} 3$ and none of enalapril. The drugs differ structurally but both inhibit angiotensin converting enzyme, also known as kininase II. ${ }^{4}$ This enzyme catalyses two important processes: the conversion of angiotensin I to angiotensin II, and the breakdown of bradykinin, a potent vasodilator agent. Angiotensin II is a potent vasoconstrictor and also stimulates the release of aldosterone from the adrenal cortex. Inhibition of the enzyme by captopril or enalapril thus leads to vasodilatation and inhibition of salt and water retention in the kidneys.

Previous studies have reported improvement in infants with heart failure treated with captopril. ${ }^{23}$ Enalapril has the advantage of a once daily regimen as compared with a three times daily regimen for captopril. As both drugs have to be freshly prepared before each dose, a once daily regimen is time saving for the nurses. Enalapril prolongs survival in adults with severe heart failure, ${ }^{4}$ but it is not known whether captopril does so. On the other hand, the long half life of enalapril may result in a delayed and prolonged hypotensive effect after the first dose, ${ }^{5}$ and the time to reach a steady state is longer.

Whereas the underlying problem in adults with heart failure is usually pump failure, in infancy it is usually volume overload as a result of large systemic to pulmonary shunts. In the former case the beneficial effects of enalapril are thought to be caused by a combination of afterload reduction and long term inhibition of salt and water retention, though in the early days of treatment net salt and water retention may occur as a result of the acute effects of enalapril on renal blood flow. ${ }^{6}$ In infants with large systemic to pulmonary shunts the causes of heart failure may be more complex. Pulmonary vascular resistance falls progressively after birth and infants with severe heart failure usually have comparatively normal pulmonary vascular resistance. ${ }^{7}$ In contrast, high catecholamine and angiotensin II concentrations as a consequence of severe heart failure usually result in high systemic vascular resistance. ${ }^{7}$ Under these circumstances enalapril might be expected to have a much greater effect on systemic than on pulmonary vascular resistance. The impressive clinical response to enalapril in our patients with shunts suggests that systemic vascular resistance fell more than pulmonary vascular resistance, resulting in an increase in systemic blood flow and a decrease in the size of the left to right shunt.

There was a pronounced and sustained clinical improvement in six of the eight patients, five of whom had large systemic to pulmonary shunts and one who had aortic coarctation. One infant (case 2) improved to such an extent that pulmonary artery banding, which had seemed inevitable, was avoided. The large ventricular septal defect responsible for this patient's heart failure has subsequently closed spontaneously, thus avoiding the need for surgery. Though case 3 did not improve after treatment with enalapril, and indeed died one week after its introduction, we believe that this was the result of progressive myocardial failure rather than an adverse effect of enalapril. Prolonged hypotension, however, is a potentially important problem that requires close monitoring of the response to treatment, particularly immediately after the first dose. One further patient had died (case 7) but this infant initially improved on enalapril, which was withdrawn after corrective surgery. The cause of death was septicaemia, acute renal failure, and worsening heart failure.

The response of the plasma sodium concentration is of some interest. Hyponatraemia is a marker of severe heart failure and is associated with high concentrations of both renin and antidiuretic hormone. ${ }^{8}$ Hyponatraemia in association with heart failure is a consequence of water overload, and the total body sodium concentration may be normal or high rather than low. ${ }^{9}$ Logical treatment therefore entails fluid restriction, but in infants this may be detrimental because of the associated calorie restriction and increased risk of vascular thrombosis. In adult 
practice angiotensin converting enzyme inhibitors often correct hyponatraemia, but the reverse may also occur, particularly in the early days of treatment. ${ }^{10}$ The response of our patients with hyponatraemia is encouraging, and suggests that the use of enalapril may reduce the need for severe fluid restriction. The mechanisms of reversal of hyponatraemia may be complicated, but probably entail an improvement in haemodynamics or a reduction in the direct antidiuretic hormone like activity of angiotensin II and the angiotensin II mediated release of antidiuretic hormone. ${ }^{11} 12$

The mean plasma urea concentration fell for the group as a whole, but rose in a single patient. A deterioration in renal function in adult patients given enalapril during the treatment of heart failure is common. ${ }^{6}$ This is thought to be associated with both a reduction in central systemic blood pressure and a decrease in transglomerular perfusion pressure. The improvement in renal function in our patients during the first two weeks of treatment suggests that the improvement in systemic blood flow and the decreased diuretic requirement with enalapril outweigh the potentially deleterious effects of enalapril on renal function.

In summary, our small study suggests that enalapril may offer a new and exciting alternative treatment for severe heart failure in infancy, particularly in patients with large systemic to pulmonary shunts. This may permit surgery to be delayed until the infant is in better condition, and temporary pulmonary artery banding may be avoided in some cases. Larger studies are required to confirm our findings and to identify possible adverse effects.

\section{References}

${ }^{1}$ Fleg JL, Gottlieb SH, Lakatta EG. Is digoxin really important in the treatment of compensated heart failure? Am J. Med 1982;73:244-50.

2 Shaw NJ, Wilson N, Dickinson DF. Captopril in heart failure secondary to a left to right shunt. Arch Dis Child 1988;63:360-3.

${ }^{3}$ Scammell AM, Arnold R, Wilkinson JL. Captopril in the treatment of infant heart failure. Int J Cardiol 1987;16:295-301.

4 The CONSENSUS trial study group. Effects of enalapril on mortality in severe congestive heart failure. $N$ Engl $J$ Med 1987;316:1429-35.

5 Cleland JGF, Dargie HJ, McAlpine H, Ball SG, Morton JJ, Robertson JIS. Severe hypertension after first dose of enalapril in heart failure. $\mathrm{Br}$ Med $J$ 1985;291:1309-12.

${ }^{6}$ Cleland JGF, Dargie HJ, Ball SG, et al. Effects of enalapril in heart failure: a double blind study of effects on exercise performance, renal function, hormones and metabolic state. $\mathrm{Br}$ Heart $J$ 1985;54:305-12.

${ }^{7}$ Talner NS. Heart failure. In: Adams FH, Emmanouilides GC, eds. Heart disease in infants, children and adolescents. 3rd ed. Baltimore: Williams and Wilkins, 1983:704-25.

${ }^{8}$ Lee WH, Packer M. Prognostic importance of serum sodium concentration and its modification by converting enzyme inhibition in patients with severe chronic heart failure. Circulation 1986;73:257-67.

9 Cleland JGF, Dargie HJ, Robertson I, et al. Total body electrolyte composition in patients with heart failure: a comparison with normal subjects and patients with untreated hypertension. Br Heart J 1987;58:230-8.

10 Packer M, Medina V, Yushak M. Correction of dilutional hyponatraemia in severe chronic heart failure by converting enzyme inhibition. Ann Intern Med 1984;100:782-9.

11 Gill JR, Barbour BH, Slater JDH, Bartter FC. Effect of angiotensin II on urinary dilution in normal man. Am J Physiol 1964;206:750-4.

12 Phillips PA, Rolls BJ, Ledingham JGG, Morton JJ, Forsling ML. Angiotensin II induced thirst and vasopressin release in man. Clin Sci 1985;68:669-74.

Correspondence to Dr KA Hallidie-Smith, Hammersmith Hospital, Du Cane Road, London W12 0HS.

Accepted 30 August 1988 